\title{
Accounting
}

\section{The effects of production and operational costs, capital structure and company growth on the profitability: Evidence from manufacturing industry}

\author{
Muhammad Istan ${ }^{a^{*}}$, Nazifah Husainah ${ }^{b}$, Murniyanto ${ }^{a}$, Asep Dadan Suganda ${ }^{c}$, Indra Siswantid and \\ Mochammad Fahlevi ${ }^{\mathrm{e}}$
}

${ }^{a}$ State Islamic Institut of Curup, Indonesia

${ }^{b}$ Fakultas Ekonomi dan Bisnis Universitas Muhammadiyah Jakarta, Indonesia

${ }^{c}$ UIN Sultan Maulana Hasanuddin, Banten, Indonesia

${ }^{d}$ Department of Management, Universitas Mercu Buana, Indonesia

${ }^{e}$ Department of Management, BINUS Online Learning, Bina Nusantara University, Indonesia

\section{H R O N I C L E}

Article history:

Received: January 24, 2021

Received in revised format:

April 252021

Accepted: April 25, 2021

Available online:

April 26, 2021

Keywords:

Production cost

Operational cost

Capital structure

Company growth

Profitability

\section{A B S T R A C T}

\begin{abstract}
The purpose of this research is to analyze the effects of production and operational costs, capital structure and company growth on profitability. The method used in this research is quantitative method, data collection is performed by distributing questionnaires among employees of packaging industry. The population in this study are industrial employees in Jabodetabek whose numbers have not been identified with certainty. The questionnaire is distributed electronically using a simple random sampling technique. The results of the questionnaire returned are 180 respondents. Based on the results of data analysis, it is concluded that Capital structure has a significant effect on profitability. An increase in the capital structure variable will be followed by an increase in profitability and a decrease in variable capital structure will be followed by a decrease in profitability. Company growth has no significant effect on profitability. An increase in the company growth variable will not be followed by an increase in profitability and a decrease in variable company growth will not be followed by a decrease in profitability. Operational cost has a significant effect on profitability. An increase in the operational cost variable will be followed by an increase in profitability and a decrease in variable operational cost will be followed by a decrease in profitability. Production cost has no significant effect on profitability. An increase in the production cost variable will not be followed by an increase in profitability and a decrease in variable production cost will not be followed by a decrease in profitability.
\end{abstract}

C) 2021 by the authors; licensee Growing Science, Canada

\section{Introduction}

Manufacturing companies are companies whose activities are to process raw materials (raw materials) into finished goods that are ready for use by the community. The special activity in a manufacturing company is processing raw materials into finished goods, this activity is often referred to as the production process. During the production process, it certainly requires production costs that occur in the processing of raw materials into finished goods, so that the finished goods are ready for sale. Production costs consist of direct material costs, direct labor costs, and factory overhead costs. Fulfilling better product quality and

\footnotetext{
* Corresponding author.

E-mail address: muhammadistan@iaincurup.ac.id (M. Istan) 
competitive prices is a challenge for the company. Moreover, these demands are accompanied by high production costs. Companies are required to be able to reduce production costs consisting of raw material costs, direct labor costs and factory overhead. According to Bakti and Kartika, (2020) and Suwandi and Hadi, (2020). in addition to providing goods that are ready for use by the community, companies must also aim to obtain maximum profit, so that the company's survival and employee welfare can be guaranteed. Profitability measures the effectiveness of management as a whole which is indicated by the size of the level of profits obtained in relation to sales and investment. The better the profitability ratio, the lower the risk of a failure. According to Maryani (2020); Novitasari, (2021); Bakti and Kartika (2020); Suwandi and Hadi (2020), the level of profit is an important factor for the company. The size of the company's profit can be found through the analysis of the company's financial statements with the profitability ratio. The profitability ratio is used by the company to find out how much profit companies get. Profitability ratio is a ratio that measures the company's ability to generate profits by using the sources owned by the company, such as assets, capital or company sales. According to Asbari (2021); Bakti and Kartika (2020); Suwandi and Hadi, (2020), to run a business, companies need capital that comes from debt and equity (equity). This source of capital can also be referred to as a source of financing or a source of funding or a source of capital. By determining the right capital structure, it will affect the size of the company's growth. According to Asbari (2021); Setiawan and Purba (2020); Fahmi et al. (2021); Maryani (2020), large companies are more in demand than small companies so that company growth greatly affects company value. Companies that grow quickly also enjoy the benefits and positive image obtained. Fast growth does not mean uncontrolled cost growth, then in managing growth, a company must have operational control with an emphasis on cost control. The company's accelerated growth may reflect the large need for funds if a company wishes to expand its business, thereby increasing the company's desire to retain profits.

According to Asbari (2021), Setiawan and Purba (2020), Suwandi and Hadi, (2020), profitability measures the effectiveness of management as a whole which is indicated by the size of the level of profits obtained in relation to sales and investment. According to Setiawan and Purba (2020), Fahmi et al. (2021), Maryani (2020), Novitasari (2021), Bakti and Kartika (2020), Suwandi and Hadi (2020), the benefits obtained are to determine the level of profit obtained by the company in one period: 1 . Knowing the company's profit position from the previous year to the current year 2. Knowing the development of profits over time 3. Knowing the amount of net profit after tax own capital 4. Knowing the productivity of all company funds used both loan capital and own capital 5. Other benefits. Cost is the sacrifice of economic resources that are measured in units of money that have occurred or are likely to occur to achieve certain objectives. According to Asbari (2021), Setiawan and Purba (2020), Fahmi (2021), Maryani (2020), Novitasari (2021), Bakti and Kartika (2020), Suwandi and Hadi (2020), production costs are the costs used in the production process consisting of direct raw materials, direct labor, and factory overhead costs. Production costs can be associated with the inventory expenses. An operating or operational cost literally consists of 2 words, namely "cost" and "operational", according to the large Indonesian dictionary, cost means money spent to procure (set up, do, and so on) something, purchases, and expenses. Meanwhile, operational is related to normal operations of the firms. Operating costs are not directly related to the company's products, but they are associated with the company's day-to-day operating activities. Capital structure is a mixture or proportion of long-term debt and equity, in order to finance its investment (operating assets). According to Asbari (2021), Setiawan and Purba (2020) and Fahmi et al. (2021), one of the factors that makes a company competitive in the long run is associated with its strong capital structure. The decision on the sources of funds used to strengthen the capital structure of a company cannot be seen growth ratio (Novitasari 2021; Bakti \& Kartika, 2020; Suwandi \& Hadi, 2020), which is a ratio that measures how much the company's ability to maintain its position in the industry and in general economic development. The growth rate is the rate of increase in sales from year to year, where the higher the company's growth, the higher the need for external capital. High growth rate tends to use debt more than companies that have slow growth. According to Suwandi and Hadi (2020), a company that is in an industry with a high growth rate must provide sufficient capital to finance the company. Companies that are growing rapidly tend to use debt more than companies that are growing slowly. High sales growth indicates an increase in the revenue the company gets from selling products in the company's operational activities. With an increase in revenue, the company will have the opportunity to expand its wings for expansion by adding new resources in order to increase the profit that the company will achieve. The purpose of this research is to analyze effects of production and operational costs, capital structure and company growth on profitability.

\section{Method}

The method used in this research is quantitative method, data collection is performed by distributing questionnaires to packaging industry employees. The method for processing data is by using PLS and using the SmartPLS version 3.0 software as a tool. The population in this study include all industrial employees in Jabodetabek whose numbers have not been identified with certainty. The questionnaire was distributed electronically using simple random sampling technique. The results of the questionnaire returned were 180 respondents. Based on the theoretical study and previous research above, the research model is as in Fig. 1. The research hypotheses are as follows:

\section{$\mathrm{H}_{1}$ : Production cost has a significant effect on profitability.}

$\mathrm{H}_{2}$ : Operational cost has a significant effect on profitability. 
$\mathrm{H}_{3}$ : Capital structure has a significant effect on profitability.

$\mathrm{H}_{4}$ : Company growth has a significant effect on profitability.

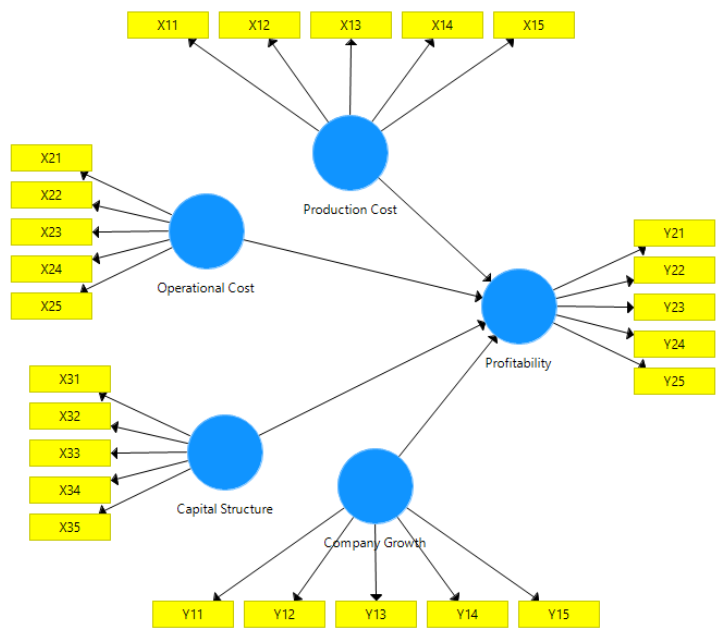

Fig. 1. Research Model

\section{Results and discussion}

Fig. 2 demonstrates the results of the personal characteristics of the participants who took part in this survey.

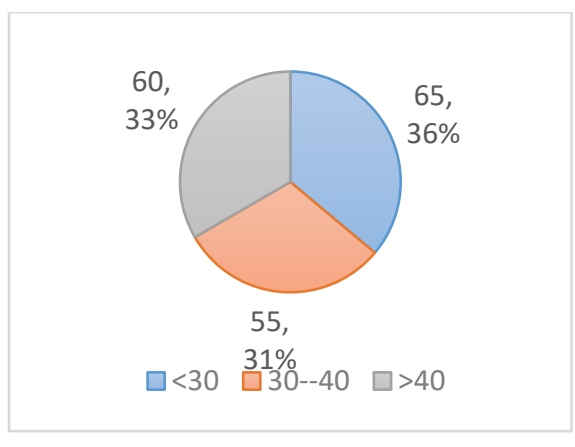

Age

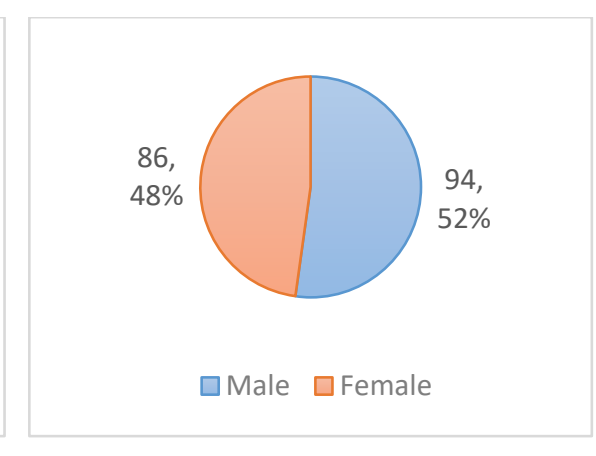

Gender

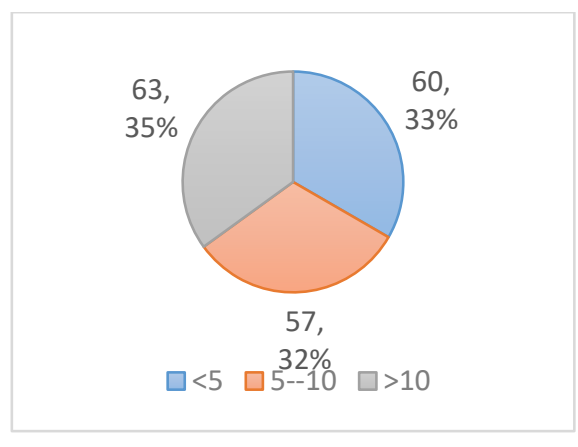

Years of work experience

Fig. 2. Personal characteristics of the participants

\subsection{The Validity and Reliability of Research Indicators}

This phase of the measurement model includes testing for convergent validity, discriminant validity and composite reliability. The results of the PLS analysis can be used to test the research hypothesis if all indicators in the PLS model have met the requirements of convergent validity, discriminant validity and reliability testing.

\section{Convergent Validity Testing}

Convergent validity test is performed by looking at the loading factor value of each indicator against the construct. In most references, a factor weight of 0.5 or more is considered to have sufficiently strong validation to explain latent constructs (Chin, 1998; Hair et al., 2010). In this study, the minimum limit for the accepted loading factor is 0.5, provided that the AVE value of each construct is $>0.5$ (Hair et al., 2010). Based on the estimation results of the PLS model in the image above, all indicators have a loading factor value above 0.5 so that the model has met the convergent validity requirements. Apart from looking at the loading factor value of each indicator, convergent validity was also assessed from the AVE value of each construct. The AVE value for each construct of this study is more than 0.5 . So the convergent validity of this research model has met the requirements. The value of loadings, Cronbach's alpha, composite reliability and AVE for each complete construct can be seen in Table 1. 
Table 1

The results of Cronbach's Alpha, Composite Reliability, and Average Variance

\begin{tabular}{|c|c|c|c|c|}
\hline & Cronbach's Alpha & rho A & Composite Reliability & Average Variance Extracted (AVE) \\
\hline Capital Structure & 0.898 & 0.972 & 0.935 & 0.827 \\
\hline Company Growth & 0.988 & 1.013 & 0.992 & 0.977 \\
\hline Operational Cost & 0.949 & 3.069 & 0.863 & 0.563 \\
\hline Production Cost & 0.933 & 0.959 & 0.948 & 0.784 \\
\hline Profitability & 0.976 & 0.983 & 0.982 & 0.916 \\
\hline
\end{tabular}

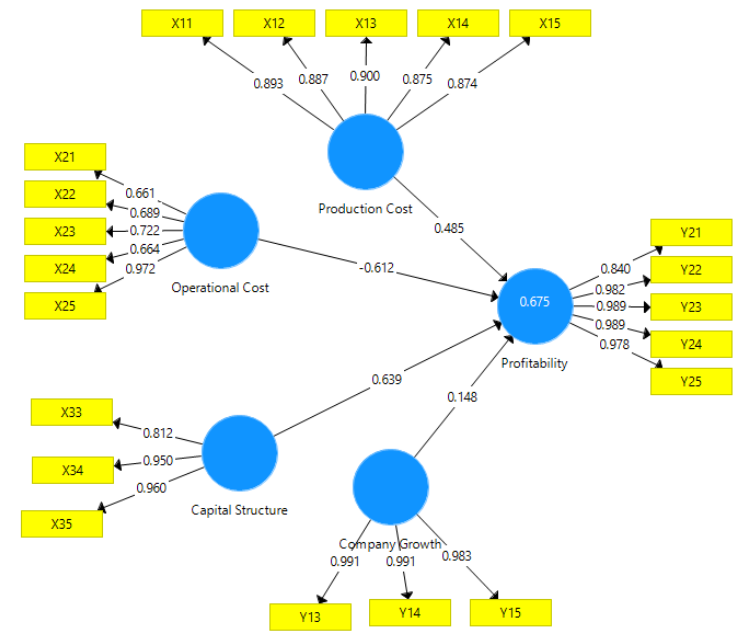

Fig 2. Model valid

\section{Construction Reliability Testing}

Construct reliability can be assessed from the Cronbach's alpha value and the composite reliability of each construct. The recommended composite reliability and Cronbach's alpha value is more than 0.7. (Hair et al., 2010). The results of the reliability test in Table 2 above show that all constructs have composite reliability and Cronbach's alpha values are greater than 0.7 (> $0.7)$. In conclusion, all constructs have met the required reliability.

\section{Discriminant Validity Testing}

Discriminant validity is done to ensure that each concept of each latent variable is different from other latent variables. The model has good discriminant validity if the AVE square value of each exogenous construct (the value on the diagonal) exceeds the correlation between this construct and other constructs (values below the diagonal) (Chin, 1998). The results of discriminant validity testing using the AVE square value, namely by looking at the Fornell-Larcker Criterion Value are obtained as follows:

Table 2

Discriminant Validity

\begin{tabular}{llllll}
\hline & Capital Structure & Company Growth & Operational Cost & Production Cost & Profitability \\
\hline Capital Structure & 0.910 & & & & \\
Company Growth & 0.299 & 0.988 & & & \\
Operational Cost & 0.084 & 0.111 & 0.751 & 0.886 & 0.138 \\
Production Cost & 0.157 & -0.075 & 0.713 & -0.196 & 0.957 \\
Profitability & 0.709 & 0.235 & & & \\
\hline
\end{tabular}

\subsection{Hypothesis testing}

Hypothesis testing in PLS is also known as the inner model test. This test includes a significance test for direct and indirect effects as well as a measurement of the magnitude of the influence of exogenous variables on endogenous variables. To determine the production cost, operational cost, company growth, capital structure on profitability, a direct and indirect effect test is needed. The effect test was performed using the t-statistic test in the partial least squared (PLS) analysis model using the SmartPLS 3.0 software. With the bootstrapping technique, the R Square value as well as Adjusted R-Square values are 0.675 and 0.660 , respectively. This means that the sales performance variable can be explained by the promotion and distribution cost variable of $67.5 \%$, while the remaining $32.5 \%$ is explained by other variables not discussed in this study. Table 3 presents the summary of the results. 
Table 3

The summary of testing the hypotheses

\begin{tabular}{|c|c|c|c|c|c|}
\hline & Original Sample $(\mathrm{O})$ & Sample Mean (M) & Standard Deviation (STDEV) & T Statistics $(|\mathrm{O} / \mathrm{STDEV}|)$ & P Values \\
\hline Capital Structure $\rightarrow$ Profitability & 0.639 & 0.708 & 0.101 & 6.318 & 0.000 \\
\hline Company Growth $\rightarrow$ Profitability & 0.148 & 0.059 & 0.105 & 1.408 & 0.160 \\
\hline Operational Cost $\rightarrow$ Profitability & -0.612 & -0.348 & 0.292 & 2.097 & 0.037 \\
\hline Production Cost $\rightarrow$ Profitability & 0.485 & 0.248 & 0.257 & 1.890 & 0.059 \\
\hline
\end{tabular}

Meanwhile, Table 3 shows the T Statistics and P-Values which show the influence between the research variables that have been mentioned.

\section{The effect capital structure on profitability}

Based on the results of the analysis in Table 6 , t-statistics is $6.318>1.96$ with p-values $0.000<0.050$ and it can be concluded that $\mathrm{H}_{1}$ is accepted, capital structure has significant effect on profitability. An increase in the capital structure variable will be followed by an increase in profitability and a decrease in variable capital structure will be followed by a decrease in profitability. The results of this study are in line with research conducted by other scholars (e.g., Ardi et al., 2020a, 2020b; Meilani et al., 2021; Mulyadi et al., 2017) where they stated that capital structure has a significant and positive effect on profitability. However, this research is not in line with research conducted by some other researchers (e.g., Sudibjo \& Sutarji, 2020; Sudibjo \& Suwarli, 2020; Wanasida et al., 2021) who concluded that the Capital Structure (DER) has no significant effect on profitability.

\section{The effect of company growth on profitability}

Based on the results of the analysis in Table 3, the t-value is $1.408<1.96$ with p-values $0.160>0.050$ and it can be concluded that $\mathrm{H}_{2}$ is rejected, company growth has no significant effect on profitability. An increase in the company growth variable will not be followed by an increase in profitability and a decrease in variable company growth will not be followed by a decrease in profitability. The results of this study are not in line with some studies (Ardi et al., 2020a, 2020b; Meilani et al., 2021; Mulyadi et al., 2017; Sudibjo \& Sutarji, 2020; Sudibjo \& Suwarli, 2020; Wanasida et al., 2021) which state that company growth does not have a significant and negative effect on profitability

\section{The effect of operational cost on profitability}

Based on the results of the analysis in Table 3, we have t-statistics is equal to $2.097>1.96$ and P-Values $0.037<0.050$ and it can be concluded that $\mathrm{H}_{3}$ is accepted, which means operational cost has a significant effect on profitability. An increase in the operational cost variable will be followed by an increase in profitability and a decrease in variable operational cost will be followed by a decrease in profitability. The results of this study are in line with some researchers (Mulyadi et al., 2017; Sudibjo \& Sutarji, 2020; Sudibjo \& Suwarli, 2020; Wanasida et al., 2021) which states that operational costs have a significant and negative effect on profitability. This means that the higher the company's operating costs, the company's profits will decrease. Likewise, if operating costs fall, the company's profits will increase.

\section{The effect of production cost on profitability}

Based on the results of the analysis in Table 3, we have t-statistics of $1.890<1.96$ and P-Values $0.059>0.050$ and it can be concluded that $\mathrm{H}_{4}$ is rejected, production cost has no significant effect on profitability. An increase in the production cost will not be followed by an increase in profitability and a decrease in variable production cost will not be followed by a decrease in profitability. The results of this study are not in line with research conducted by Ardi et al. (2020a, 2020b) and Meilani et al. (2021) which states that production costs have a significant effect with a negative effect on profitability. However, this conclusion is not in line with research conducted by Haloho (2006) which states that production costs do not have a significant effect on profits.

\section{Conclusion}

The results of this study have indicated that dividend policy had a significant and negative effect on capital structure, company growth had a significant and negative effect on capital structure, dividend policy had a significant and positive effect on profitability, company growth had no significant and negative effect on profitability, capital structure had a significant and negative effect on profitability. The results are consistent with other studies (Asbari, 2021; Setiawan \& Purba, 2020; Fahmi, 2021; Bakti \& Kartika, 2020; Suwandi \& Hadi, 2020). Capital structure has a significant effect on profitability. An increase in the capital structure variable will be followed by an increase in profitability and a decrease in variable capital structure will be followed by a decrease in profitability. Company growth has no significant effect on profitability. An increase in the company growth variable will not be followed by an increase in profitability and a decrease in variable company growth will not be followed by a decrease in profitability. Operational cost has a significant effect on profitability. An increase in the operational cost variable will be followed by an increase in profitability and a decrease in variable operational cost will be followed by a 
decrease in profitability. Production cost has no significant effect on profitability. An increase in the production cost variable will not be followed by an increase in profitability and a decrease in variable production cost will not be followed by a decrease in profitability. Investors who want to invest in a company should pay attention to the level of debt owned by the company, because the capital structure that can increase the company's profitability shows that the company's financial performance is good. This can provide benefits for companies as well as investors. This study has shown that the capital structure that uses the Debt to Equity Ratio (DER) and has a significant and positive effect on profitability in manufacturing companies. For further research, it is hoped that further research can add more variables that are considered to have an effect on profitability, such as Leverage, Quick Ratio, Company Size, Net Profit Margin, and Return on Assets.

\section{References}

Asbari, M., Dylmoon Hidayat, D., \& Purwanto, A. (2021). Managing Employee Performance: From Leadership to Readiness for Change. International Journal of Social and Management Studies, 2(1), 74-85. https://doi.org/10.5555/ijosmas.v2i1.12

Ardi, A., Djati, S. P., Bernarto, I., Sudibjo, N., Yulianeu, A., Nanda, H. A., \& Nanda, K. A. (2020a). The Relationship Between Digital Transformational Leadership Styles and Knowledge-Based Empowering Interaction for Increasing Organisational Innovativeness. International Journal of Innovation, Creativity and Change, 11(3), 259-277.

Ardi, A., Djati, S. P., Bernarto, I., Sudibjo, N., Yulianeu, A., Nanda, H. A., \& Nanda, K. A. (2020b). The Secret to Enhancing Innovativeness in the Digital Industry. International Journal of Innovation, Creativity and Change, 12(12), $225-243$.

Bakti, C. S., \& Kartika, H. (2020). Analysis of Ice Cream Product Quality Control With Six Sigma Method. Journal of Industrial Engineering \& Management Research, 1(1), 63-69.

Chin, W. W. (1998). The partial least squares approach to structural equation modeling. Modern methods for business research, 295(2), 295-336.

Fahmi, K., Mustofa, A., Rochmad, I., Sulastri, E., Wahyuni, I. S., \& Irwansyah, I. (2021). Effect of ISO 9001: 2015 , ISO 14001: 2015 and ISO 45001: 2018 on operational performance of automotive industries. Journal of Industrial Engineering \& Management Research, 2(1), 13-25. https://doi.org/10.7777/jiemar.v2i1.110

Hair, J. F., Anderson, R. E., Babin, B. J., \& Black, W. C. (2010). Multivariate data analysis: A global perspective (Vol. 7).

Maryani, E., Purba, H. H., \& Sunadi, S. (2020). Process Capability Improvement Through DMAIC Method for Aluminium Alloy Wheels Casting. Journal of Industrial Engineering \& Management Research, 1(4), 19-26. https://doi.org/10.7777/jiemar.v1i4.98

Meilani, Y. F. C. P., Tan, J. D., Murwani, F. D., Bernarto, I., \& Sudibjo, N. (2021). Motivating and retaining generation z faculty members in private universities. Journal of Educational and Social Research, 11(1), 245-255. https://doi.org/10.36941/jesr2021-0022

Mulyadi, Sudibjo, N., \& Bernarto, I. (2017). The Effect of Perceived Organizational Support, Work Engagement, and Job Satisfaction on Teacher's Performance at Xyz Middle and High School. International Journal of Economic Research, 14(13), 7-19.

Novitasari, D., Asbari, M., \& PURWANTO, A. (2021). Maximizing Employee Performance: An Analysis of Organizational and Individual Factors. International Journal of Social and Management Studies, 1(1), 95-104. https://doi.org/10.5555/ijosmas.v1i1.11

Setiawan, I., \& Purba, H. H. (2020). A Systematic Literature Review of Key Performance Indicators (KPIs) Implementation. Journal of Industrial Engineering \& Management Research, 1(3), 200-208. https://doi.org/10.7777/jiemar.v1i3.79

Suwandi, S., \& Hadi, A. H. (2020). Value Analysis Method For Cost Reduction Analysis of Fuel Filter Poducts at PT Duta Nichirindo Pratama. Journal of Industrial Engineering \& Management Research, 1(1), 28-36. https://doi.org/10.7777/jiemar.v1i1.22

Sudibjo, N., \& Sutarji, T. (2020). The roles of job satisfaction, well-being, and emotional intelligence in enhancing the teachers' em- ployee engagements. Management Science Letters, 10, 2477-2482. https://doi.org/10.5267/j.msl.2020.4.002

Sudibjo, N., \& Suwarli, M. B. N. (2020). Job Embeddedness and Job Satisfaction as a Mediator between Work-Life Balance and Intention to Stay. International Journal of Innovation, Creativity and Change, 11(8), 311-331.

Wanasida, A. S., Bernarto, I., Sudibjo, N., \& Pramono, R. (2021). Millennial Transformational Leadership on Organizational Performance in Indonesia Fishery Startup. Journal of Asian Finance, Economics and Business, 8(2), 555-562. https://doi.org/10.13106/jafeb.2021.vol8.no2.0555

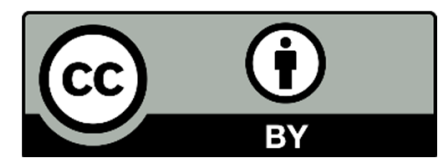

(C) 2021 by the authors; licensee Growing Science, Canada. This is an open access article distributed under the terms and conditions of the Creative Commons Attribution (CC-BY). license (http://creativecommons.org/licenses/by/4.0/). 